\title{
Recent Eco-Friendly Developments in Personal Protective Clothing Materials for Reducing Plastic Pollution: A Review
}

\author{
Arshad Hussain Memon \\ Institute of Environmental Engineering and \\ Management, Mehran University of \\ Engineering and Technology, \\ Jamshoro, Pakistan \\ arshad.memon@hotmail.com
}

\author{
Sheeraz Ahmed Memon \\ Institute of Environmental Engineering and \\ Management, Mehran University of \\ Engineering and Technology, \\ Jamshoro, Pakistan \\ sheerazahmed.memon@faculty.muet.edu.pk
}

\author{
Mazhar Hussain Peerzada \\ Department of Textile Engineering, \\ Mehran University of Engineering and \\ Technology, \\ Jamshoro, Pakistan \\ mazhar.peerzada@faculty.muet.edu.pk
}

\author{
Sajjad Ali Mangi \\ Department of Civil Engineering, \\ Mehran University of Engineering and \\ Technology, SZAB Campus, \\ Khairpur Mir's, Pakistan \\ sajjad.nec@gmail.com
}

\author{
Khan Muhammad \\ Institute of Environmental Engineering \\ and Management, Mehran University \\ of Engineering and Technology, \\ Jamshoro, Pakistan \\ dean.foapand@admin.muet.edu.pk \\ Ghulam Mujtaba \\ Energy and Environment Engineering \\ Departement, Dawood University of \\ Engineering and Technology, \\ Karachi, Pakistan \\ gmujtabaawan@gmail.com
}

\begin{abstract}
Due to the industrialization increase in the 20th century, the level of hazards for public health and the demand for personnel protective clothing (PPC) have increased. The area of PPC has been steered to high tech equipment made from plastic-based materials, which are derived from non-renewable sources and have a long life cycle expanding from hundreds to thousands of years, after their end of useful life. This paper reviews the information related to conventional plastic-based fibers, their properties, advantages, disadvantages, and applications in the battlefield, industry, automobiles, etc. This paper provides a basis for the selection of natural fibers and the replacement of conventional plastic-based fibers to reduce the plastic content in protective clothing or other composites. A comparative analysis of technological, environmental, economic and legal aspects of plastic-based and environment-friendly natural fibers is presented. Natural fiber-based composite protective clothing is found to be environment-friendly and considered to have prospects for the future due to its comparative technological, environmental, economic and legal advantages.
\end{abstract}

Keywords-eco-friendly fibers; conventional plastic fibers; protective clothing; plastic pollution; kevlar; UHMPE; Jute and Ramie

\section{INTRODUCTION}

Plastic waste is a major environmental issue, which if not dealt properly could be potentially hazardous [1]. It is estimated that 8,300 million metric tons (Mt) of virgin/nonrecycled plastics have been produced. By 2015, almost $6,300 \mathrm{Mt}$ of plastic waste were generated, out of which, around $9 \%$ have been recycled, $12 \%$ incinerated, and $79 \%$ added up in landfills or simply dumped in the environment. If current production and waste management rate continues, it is estimated that almost $12,000 \mathrm{Mt}$ of plastic waste will be landfilled or dumped by $2050[2,3]$. The late $20^{\text {th }}$ century saw an unmatched increase in the emphasis of protection from occupational hazards. Increasingly complex legislation, regulation and environmental awareness in workplaces were the result of the new philosophy. The range of hazards and the means of combating them continue to grow and become even more complex. A consequence of this is the development of new textile fibres, structures, and clothing systems whose purpose is to provide improved protection, whilst maintaining comfort, efficiency, and well-being [4, 5]. High strength polymers are commonly used in protective clothing due to their favourable mechanical properties, such as cut, impact, and chemical resistance. High-performance fibers such as aramid fiber (aromatic polyamide), ultra-high molecular weight polyethylene (UHMWPE) fibers, and Zylon ${ }^{\circledR}$ (p-phenylene-26 benzobisoxaazole) have excellent performance and are being used in PPC, marine industry, etc. [6]. Having the characteristics of the plastic family, on the other hand, causes various environmental problems in disposal by incineration. In the case of incomplete incineration, emissions released in the atmosphere can cause hazards for public health or the environment. Plastic-based fibers derived from the petroleum products are not eco-friendly and have a very long life spanning from hundreds to thousands of years, while they are toxic [6]. Raw material sources of these fibers are nonrenewable and expensive when compared to natural fibers. Thus, in order to address these issues, eco-friendly/renewable resources should be utilized in composite materials and natural fibres may be added as reinforcement fibres $[7,8]$. 
Lack of biodegradability, closing of landfill sites, and the increase in water, air, and land pollution issues, led to reluctance towards the use of plastics materials $[9,10]$. Most of plastic is non-biodegradable and remains in the environment for years after its disposal. Recycling has practically failed to provide an environmentally safe solution for the disposal of plastic waste. In the dearth of efficient techniques for safe disposal of plastic wastes, they are accumulated in the ecosystem and pose an ecological threat. With the passage of time, this plastic waste converts in microplastics which accumulate in the marine and terrestrial environment. These microplastics can be ingested by animals and fish, and penetrate the food chain, becoming potentially hazardous for human health [11]. Due to the increase in the awareness that non-renewable sources are becoming meager, markets started to look at renewable sources of fibers, like natural fibers. Various studies were carried out regarding the replacement of plastic fibers with natural fibees in the field of protective clothing. This era witnessed notable successes in green technology in the field of material science through the development of bio-composites. The development of highperformance materials made from natural resources is increasing worldwide. The greatest challenge in working with natural fiber reinforced plastic composites is their large variation in properties and characteristics [12].

This paper provides information related to conventional plastic-based fibers, which include high-strength, highmodulus, high-performance, and high-chemical and combustion resistant fibers, their properties, advantages, disadvantages and applications in battlefield, industry, automobiles etc. Also, information for the selection of natural fibers and partial reduction options of conventional plastic based fibers, are provided. A comparative analysis of technological, environmental, economic and legal aspects of plastic-based and environment-friendly natural fibers is presented. This paper also provides properties, advantages, disadvantages, and applications of natural fibers in protective textile and other composites.

\section{CONVENTIONAL PLASTIC BASED FIBERS FOR PC}

Protective clothing (PC) requires the combination of various properties, depending on its end use and the severity of hazard involved: cut, impact, bullet, heat, cold, chemical, and bacterial hazards. The increasing requirements of legislations related to the human health and environment protection have applied pressure on new technologies and researchers to produce fibers, fabrics, new designs, and chemicals finishes which can provide protection against a high level of hazards involved in different kinds of jobs varying from industry to industry. Simultaneously, due to environmental protection requirements, $\mathrm{PC}$ must be environment-friendly.

In primeval years, a wide variety of natural fibers including abaca, bamboo, ramie, jute, kenaf etc. were used for the protection of the human body from weather and battle hazards. In recent years, as the severity and lethal impacts of arms has been increasing, high-performance fibers aramid, carbon, and glass are used in various applications. From the literature review, it has been shown that plastic-based fibers are being used in protective clothing for different applications such as industrial tech, sports tech, defense, marine, and geotextiles. The physical properties of conventional plastic fibers are given in Table I.

TABLE I. PHYSICAL PROPERTIES OF CONVENTIONAL/PLASTICBASED FIBERS

\begin{tabular}{|c|c|c|c|c|}
\hline Fiber/material type & p-aramid & UHWMP & Carbon & $\begin{array}{l}\text { Meta aramid } \\
\text { (nomex/ conex) }\end{array}$ \\
\hline Strength (MPa) & 2900 & 4000 & 3600 & \\
\hline Specific gravity & 1.4 & 1.0 & 1.8 & 1.38 \\
\hline Modulus (MPa) & 95 & 95 & 400 & 75 \\
\hline Breaking elongation & 3.5 & 4.0 & 1.7 & 2.5 \\
\hline Density $\left(\mathrm{g} / \mathrm{cm}^{3}\right)$ & 1.44 & 0.97 & $1.8-2.1$ & 1.38 \\
\hline $\begin{array}{c}\text { Melting point/heat } \\
\text { resistance }\left({ }^{\circ} \mathrm{C}\right)\end{array}$ & 550 & 150 & $>2500$ & 425 \\
\hline Moisture regain \% & 5 & 0 & 0 & 4.5 \\
\hline $\begin{array}{c}\text { Limiting oxygen } \\
\text { index }\end{array}$ & 29 & 20 & & 30 \\
\hline
\end{tabular}

\section{A. Classification of Conventional Fibers}

Conventional plastic fibers are classified in the following three major categories:

\section{1) High Strength -High Modulus (Organic Fibres)}

- Para-aramid fibers, Kevlar, Tawron.

- Ultra-high molecular weight polyethylene e.g., Dynema (DSM) and Spectra .

\section{2) High Performance (Inorganic Fibers)}

- Carbon

- Ceramics

- Tungsten

- Alumina

3) High Chemical and Combustion-Resistant

- Meta-aramid fibers, e.g. Nomex and Conex.

- Kermel.

- Kynol.

- Oxidized acrylic fibers, e.g. Panox.

This paper presents details of the major fibres like Paramid, UHWMPE, carbon, and M-aramid used in protective clothing and other composites.

\section{B. High Strength -High Modulus (Organic Fibers)}

Fibers under this category have high strength and modulus, making them suitable for protective applications. They are impact and cut through resistant. These inherent properties of fibers help them to retain their shape during and after impact.

\section{1) P-Aramid Fibers}

$\mathrm{P}$-aramid fibers are high-performance organic fibers having properties such as high strength, high stiffness, high toughness, damage tolerance, durability, and heat and impact resistance. Aramid is an organic-based fiber classified as p-aramid and meta-aramid. P-aramid material class has various commercial brands available in the global market, Kevlar is the first 
commercial product introduced by DuPont in early 70's, and its chemistry is based on p-phenylene terephthalamide. Kevlar represents the largest global volume product, followed by Tawron of the same chemistry group [13]. P-aramid fibres compine high strength, non-flammability and high-temperature resistance which makes them fit for use in applications such as ballistic protection in bulletproof vests and helmets, cut through protection in arms, safety gloves, shoes in high-risk industries, and aprons [5] .

\section{2) Kevlar}

Kevlar is the first commercial product based on pphenylene terephthalamide. Kevlar is used as a reinforcement material and became popular due to its excellent mechanical properties, unique flexibility, lightweight and corrosion resistance when compared with other metallic materials used for human body protection [14]. Kevlar has comparatively lower fiber elongation, high tensile strength, and modulus than other synthetic fibers. There are various product types of Kevlar available in the market. These products have different applications and properties. Kevlar ${ }^{\circledR}$ is used in tires of $4 \times 4$ vehicles. $\operatorname{Kevlar}{ }^{\circledR} 29$ is a highly engineered material, lightweight and non-flammable, used in the manufacturing of body armor (panels) for military vehicles, body armor of bulletproof jackets and bombproof suits. $\operatorname{Kevlar}{ }^{\circledR} 49$ is comparatively lightweight, like glass fibers and metals used in industry. This material found its application in aerospace industry (Eurofighter), and boat hulls due to its low weight, resistance to torque, and high impact resistance [15].

Kevlar textiles tend to absorb moisture, this can be overcome with the use of natural fibers having hydrophilic properties to protect the Kevlar from degradation and to provide comfort when used in protective clothing. Kevlar counters well under tensile force (stretching force). Unfortunately, it fails in compression strength where load bearing is required, like buildings or bridges. It is difficult and requires special cutting tools and equipment to cut and shape due to its high strength. Kevlar is sensitive to U.V. light unless covered from direct sunlight. It is also sensitive to chlorine bleaches [15]. Kevlar fiber is non-biodegradable, upon burning or incineration generates hazardous gases similar to wool fiber, including mainly carbon dioxide, nitrogen oxide, and fractional amounts of hydrogen cyanide, ammonia, aldehydes, etc. [16]. Extensive research was performed to augment the properties of Kevlar hybridization between synthetic fibers like carbon, glass, aluminum, etc. Studies focused on increasing the mechanical performance of the synthetic fiber. However, very little research was performed for the hybridization of Kevlar and natural fibers [14]. A study was performed to decrease the static and fatigue strength through hybridization of Kevlar/epoxy composites with the addition of natural fiber cork powder filler [17]. The static and fatigue strength of the composite due to the increase in the hygroscopic nature of hybrid composite was decreased.

\section{3) Ultra High Weight Molecular Polyethylene (UHWMPE)}

The UHWMPE is a highly oriented and low density crystalline produced with specific gel spinning and drawing. This method decreases the molecular defect rate. UHWMPE is commercially available under the names of Dyneema and Spectra [5]. UHWMPE fiber has various advantages, including low specific gravity and high specific strength/tenacity as shown in Table I. It has high impact resistance, weather resistance, high abrasion resistance, high flexural resistance, and vibration dampening coefficient [18]. On the other hand, UHWMPE has a very low melting point $\left(150^{\circ} \mathrm{C}\right)$ compared to P-aramid and Carbon fibers. UHWMPE has a wide range of applications in various products like bulletproof jackets, helmets, ropes, cut resistant gloves, sleeves, butcher gowns, sport nets, medical applications, and fishing lines [5, 19]. In [20], it is reported that when compared with natural fibers, UHMWPE has ultra-high strength and modulus, and good impact resistance. It is inserted as reinforcement in composites. The disadvantages of UHWMPE fiber are that it is a plastic based fiber, non-biodegradable, non-renewable, has low surface hardness, strength and stiffness, poor creep resistance, bad adhesive wear and fatigue wear resistance, poor flow behavior and consequently is difficulty in processing [21].

\section{High Performance (Organic Fibers)}

\section{1) Carbon Fiber}

Carbon is a high-performance organic fiber, produced by spinning and thermally carbonizing the precursor material. Properties and microstructure of produced carbon fiber can vary with the production method applied. About $90 \%$ of commercially produced carbon fiber is a PAN-based precursor [13]. Isotropic pitch method is used for low strength carbon fiber manufacturing and mesophase pitch for high strength fibers [6]. The advantages of carbon fiber are its high tensile strength, high modulus, low thermal expansion coefficient, high fatigue strength, good thermal electric stability and chemical resistance, gas absorption capability, and noncorrosive nature. Carbon fiber has some disadvantages. It is non-biodegradable, and has high cost, poor bending rigidity, and poor compressive strength [22]. Carbon fiber is difficult to recycle, generates a high quantity of waste during processing while recycled carbon has generally low strength. Another major disadvantage is its lack of elasticity, abrasion resistance, and electrical conductivity [23]. Due to its high-end properties, carbon fiber is highly desirable in various industrial applications such as gas purification, respiratory filters, water filters, automobiles, sports tech, aerospace, marine transport, and medical applications [24, 25].

\section{High Chemical and Combustion-Resistant Fibers}

There are various high chemical and combustion resistant organic fibers, like meta-aramid, kernel, kynol, and oxidized acrylic fibers. Most popular fibers are meta-aramid fibers (Nomex and Conex) used in protective textiles.

\section{1) Meta-Aramid (Nomex and Conex)}

The first ever aramid to be commercialized was the metaaramid polymer [m-phenylene isophthalamide] Nomex (DuPont) in 1967 [6]. M-aramid is a highly heat resistant organic fiber [18]. Meta-aramid has $100 \%$ aromatic content, due to which it offers high heat resistance up to $425^{\circ} \mathrm{C}$. The aromatic composition is responsible for excellent performance in flame, leads to swelled char, which also tips to additional thermal insulation. These fibers are now available in paper 
form for easy structural applications. M-aramid fibers have vast functionalities, which include high stiffness, high strength, high toughness, damage tolerance, and flame resistance [13]. Maramids are also chemical resistant to acid, alkalis and organic solvents. M-aramids are low tenacity and low modulus fibers, whereas they are sensitive to U.V. light and sunlight. They are not dyeable with conventional dyeing methods, however, they have some affinity with a few cationic dyes [23]. Meta-aramid fiber Nomex is used in firefighter's suits, heat resistant gloves, hot gas filtration, automotive hoses, electrical insulation, aircraft parts, and sports tech.

\section{ENVIRONMENT-FRIENDLY FIBERS}

Natural fibers reviewed for their application and suitability in protective clothing, are abaca, bamboo, coir, ramie, jute, flax, and kenaf. Natural fibers are eco-friendly materials, which have good properties compared to conventional synthetic fibers. Natural fibers have comparatively low weight, low cost, are relatively less damaging to processing equipment, and are environment-friendly. A comparison of natural and conventional plastic-based fibres is presented in Table II.

TABLE II. COMPARISON OF NATURAL AND CONVENTIONAL FIBERS

\begin{tabular}{|c|c|c|c|}
\hline Parameter & Characteristics & $\begin{array}{c}\text { Eco friendly/ } \\
\text { natural fiber }\end{array}$ & $\begin{array}{c}\text { Conventional/ } \\
\text { synthetic fiber }\end{array}$ \\
\hline \multirow{4}{*}{$\begin{array}{c}\text { Technical/ } \\
\text { Technological }\end{array}$} & Mechanical properties & Moderate & High \\
\cline { 2 - 4 } & Moisture sensitivity & High & Low \\
\cline { 2 - 4 } & Thermal sensitivity & High & Low-high \\
\cline { 2 - 4 } & Weight & Low & Heavy \\
\cline { 2 - 4 } & Abrasiveness & Low & High \\
\hline \multirow{4}{*}{ Environmental } & Aachinery required & Low-tech & High-tech \\
\cline { 2 - 4 } & Productility & Renewable & Non-renewable \\
\cline { 2 - 4 } & Method of disposal & Low & High \\
\cline { 2 - 4 } & Biodegradability & Complete & $\begin{array}{c}\text { Incinerate \& } \\
\text { recycling }\end{array}$ \\
\cline { 2 - 4 } & Energy consumption & Low & No \\
\hline Economical & Cost & Low & High \\
\hline Legal & Patents & No patents & Patents \\
\hline
\end{tabular}

The environmental characteristics of natural fibers are more favourable, however due to some properties like high strength, high abrasive strength, and high modulus, synthetic fibers are still preferred by end-users.

\section{TYPES OF ECO-FRIENDLY FIBERS}

There are six major types of natural fibres, classified upon their source of production: plants which produce cellulose are known as bast fibers such as jute, flax, ramie, hemp, and kenaf, while cotton, coir, and kapok are known as seed fibers. Leaf fibers come from abaca, sisal, and pineapple [4, 11]. The mechanical properties of natural fibers are given in Table III. Images of the plants, and views of the fibers can be seen in [28].

\section{A. Abaca}

Abaca fiber, also known as Manila hemp, is an herbaceous plant, belonging to the Musaceae family, looks like a banana plant, but it is entirely different in characteristics and applications [26]. Abaca fiber is a leaf-based fiber and has $15 \%$ lignin content. Abaca has high mechanical strength, which is three times stronger than sisal, it is a bouncy resistant and long fiber with length up to $3.7 \mathrm{~m}$ [27]. It is resistant to salt-water, which differentiates it from other vegetable fibers. It originates from Philippines and is one major export product $[4,26]$. Tensile strength and e-modulus are important parameters of abaca fiber, specifically for aerospace and automotive applications. Abaca fiber possesses higher tensile strength and low elongation in dry and wet conditions compared to synthetic fibers like rayon [27]. Abaca has applications in pulp and paper currency paper, cigarette filters, toiletries, lens cleansing, tea bags, and other related products. Its composites have uses for aerospace and automotive industries. Geotextiles of abaca are used for environmental protection specifically for soil conservation and control of soil erosion. New applications of natural fibers are on the rise, e.g. the preparation of cellulose nanocrystals as composite components. However, threats and emerging issues are concerns in the sustainability of the abaca growing areas [26, 27].

TABLE III. NATURAL FIBERS PROPERTIES [12]

\begin{tabular}{|c|c|c|c|c|}
\hline Fiber & $\begin{array}{c}\text { Tensile } \\
\text { strength } \mathbf{( M P a})\end{array}$ & $\begin{array}{c}\text { Stiffness /Young's } \\
\text { modulus (GPa) }\end{array}$ & $\begin{array}{c}\text { Elongation at } \\
\text { break } \mathbf{( \% )}\end{array}$ & $\begin{array}{c}\text { Density } \\
\left(\mathbf{g} / \mathbf{c m}^{\mathbf{3}} \mathbf{)}\right.\end{array}$ \\
\hline Abaca & 400 & 12 & $3-10$ & 1.5 \\
\hline Bamboo & $140-230$ & $1-17$ & - & $0.6-1.1$ \\
\hline Coir & 175 & $4-6$ & 30 & 1.2 \\
\hline Flax & $345-1035$ & 27.6 & $2.7-3.2$ & 1.5 \\
\hline Hemp & 690 & 70 & 1.6 & 1.48 \\
\hline Jute & $393-773$ & 26.5 & $1.5-1.8$ & 1.3 \\
\hline Kenaf & 930 & 53 & 1.6 & - \\
\hline Sisal & $511-635$ & $9.4-22$ & $2.0-2.5$ & 1.5 \\
\hline Ramie & 560 & 24.5 & 2.5 & 1.5 \\
\hline Oil Palm & 248 & 3.2 & 25 & 0.71 .55 \\
\hline Pineapple & $400-627$ & 1.44 & 14.5 & $0.8-1.6$ \\
\hline
\end{tabular}

\section{B. Coir}

Coir fiber is considered as the most green fiber as it utilizes less energy. Coir fiber is obtained from tissues around the seed of coconut palm positioned between the husk and the outer shell of the coconut [29]. It is cultivated mainly in India and Sri Lanka. There are two types of coir fibers, brown coarse fiber, and white fine fiber. The brown fiber is obtained from mature brown coconuts and the white fiber is obtained from the raw green coconuts. The length of coir is measured up to $35 \mathrm{~cm}$. Among its group, it has one of the highest contents of lignin making it stronger than cotton, but less flexible [30]. Coir fiber is natural and renewable, it has high water retention, it is moth and rot resistant, and it is a good insulator of heat and sound. Coir fiber has low cost, low density and is biodegradable with zero carbon footprint. Coir based geotextiles have been developed for application towards soil erosion control, ground improvement, etc. [29]. The traditional applications of coir fiber are ropes, carpets or mattress but nowadays it has wide applications in protective textiles like bulletproof vests and flame-resistant boards [31, 32]. It has also found application in construction industry, due to its higher strength, conventional cement tiles are replaced with coir hybrid tiles. Coir fiber has some disadvantages, including hydrophilic behavior, dimensional unstability, and low thermal resistance. Its properties vary with the area of production and climate [33]. 


\section{Bamboo}

Bamboo is a regenerated cellulose fiber and perennial plant considered as eco-friendly and sustainable [12]. Bamboo is a fast-growing plant (1 meter/day for some species) having the ability to absorb greenhouse gases, with the rate of five times more $\mathrm{CO}_{2}$ than an equivalent stand of trees and producing $35 \%$ more oxygen, while it can prevent soil erosion. According to NFI, bamboo is considered the second highest produced fiber after cotton. Bamboo is cultivated in tropical and sub-tropical areas like China, Japan, and other Asian countries. Out of 1250 species of bamboo, 400 are found and processed in China. Bamboo fibers are similar in structure to ramie fiber but shorter and finer. The length of bamboo fiber is very small and varies from $1 \mathrm{~mm}$ to $5 \mathrm{~mm}$ (with an average of $2.8 \mathrm{~mm}$ ) and diameter of $14 \mu \mathrm{m}-27 \mu \mathrm{m}$ (average $20 \mu \mathrm{m}$ ). It has antifungal and antimicrobial properties [34]. Bamboo fiber has various other advantages like high strength with low density, and high specific strength to its weight due to the longitudinal alignment of fibers in its body. Due to its high strength, bamboo is known as "natural glass fiber" [35]. Bamboo fibers found usage in traditional textile as well as in modern composites textiles [38]. Applications of bamboo fibers are reported in the construction industry, traditional clothing, protective clothing, and medical textiles. Due to inherent antimicrobial and antifungal properties, bamboo fibers are used in wound bandages, hygienic and odour resistant cloths, sports tech clothing, and sun protection clothing [34-37]. Other advantages of bamboo fiber include that it is renewable, its efficient space consumption, its low water requirements, and organic status. Disadvantages of bamboo fiber are that during processing it requires a high amount of energy, hazardous chemicals for processing, and more water compared to synthetic fibres [37].

\section{Jute}

Jute is named as "Golden fiber". It is separated from the bark of the white jute plant and to a lesser degree from tossa jute, which includes 100 species. It is an inexpensive natural fiber and abundantly available in Bangladesh, China and India with humidity of $60 \%$ to $90 \%$. Jute is an environment-friendly fiber, a hectare of jute plants absorbs around 15 tons of $\mathrm{CO}_{2}$ and releases 11 tons of oxygen. Yields are around 2 tons of dry jute fiber per hectare $[12,39]$. Jute is long, delicate and shiny, with a length of $1 \mathrm{~m}$ to $4 \mathrm{~m}$ and a diameter from $17 \mu \mathrm{m}$ to $20 \mu \mathrm{m}$. It is one of nature's toughest vegetable fibers and positions second just to cotton in production quantity. Jute has high insulating and antistatic properties, moderate moisture regain of $13 \%$ and low thermal conductivity [40]. Due to its versatile characteristics, jute fiber is used in various applications from clothing to industry. Its main advantages are its high modulus, strength and dimension stability, moderate draping and stiffness, biodegradability/eco-friendliness, high moisture absorption and breathability, and low cost. It is annually renewable, while it is abundantly grown in Bangladesh and India. Jute yarn is traditionally used in twine and sacks for the storage of grains and other food-related products, curtains, chair covers, carpets, and rugs. Jute traditionally is blended with other natural fibers used in wall hangings, toys, and lamp sheds. In addition to this, jute fiber is used in various sectors of technical textiles like agro tech, automobiles, geo-tech, industrial textile etc. Products of jute fiber are biodegradable, flexible, absorb moisture, drain well, and are helpful to prevent soil erosion [39-41]. The major disadvantages of jute fiber, which restrict its uses, are its rough nature, harsh feel, surface fuzziness, prominent hairiness, and poor washability [42]. Jute fiber enjoys favour in the market due to its environment friendly properties. It is reported that jute is more environmentfriendly and less expensive than conventional synthetic materials. Life cycle assessment study of conventional and jute fiber shows that the disposal of conventional synthetic material is causing more damage to the environment than jute [41]. Natural fibers are used as reinforcement replacing the expensive glass fibers in polymer composites [6]. Plywood, medium density fiberboards, panel, and plush doors are developed from jute and coir based composites. The addition of jute fiber $(12 \%-24 \%)$ in glass showed an increase in the mechanical properties of the composites. Hence, jute fiber shows an effective and value-added application. Other applications of jute-polyester composites are lampshades, suitcases, paperweights, helmets, bath units, electrical appliances, covers, pipes, post-boxes, roof tiles, grain storage silos, panels for partition and false ceilings, biogas containers, and low cost mobile and pre-fabricated buildings.

\section{E. Ramie}

Ramie fiber is a bast fiber and belongs to Boehmeria nivea Urticaseae, commonly known as "China Grass" which includes over 100 species, mostly grown in China. Barks of ramie fiber are used for the making of twine threads, and spun as grasscloth or Chinese linen. Ramie fiber is more like flax in absorbency and density but coarser with diameter of 25-30 microns. It is also one of the strongest natural fibers with a tensile strength of $560 \mathrm{MPa}$, more than coir $(175 \mathrm{MPa})$ and abaca (400MPa) while it is denser than bamboo [12]. Ramie as a natural fiber has various advantages, such as: it is environment-friendly, resistant to bacteria, mildew and insects, it is highly moisture absorbent, easily dyeable, and in wet condition it increases strength like cotton [26]. A major disadvantage of ramie is that its chemical characteristics vary with its area of production, which requires more pre-treatment process than any other natural fiber [12]. Other disadvantages are its low elasticity and abrasion, it wrinkles easily, and it is stiff and brittle in nature [26]. Rami is utilized as a part of body armor, it is lightweight and has low cost in comparison with conservative bulletproof panels. Results of impact resistance tests reveal that vests produced using ramie fiber could oppose the infiltration of high impact shots up to level II, and it could not avoid the impact resistance of level IV [12, 43]. Ramie fiber is used in various applications such as in industrial sewing threads, packaging material, fishing net, filter cloths, and home furnishing cloths. Short fibers of ramie are used in high-class papers such as bank notes and security papers [44].

\section{F. Flax}

Flax is a bast fiber, belongs to Linum usitatissimum L. family, and is one of the oldest fiber crops in the world [12]. Flax grows in moist climates, like Europe, China, and Egypt. Flax is an environment-friendly fiber used in high-end textile products. The flax plant has a life cycle of 90-125 days, which includes vegetation, blossoming and ripening periods [45]. Flax fiber is breathable and provides comforts during wearing, 
absorbs sweat and is a good heat exchanger, which reduces body temperature during summer. During winter, flex fiber does not attract electrostatic charges, provides psychophysical comfort [26]. Flax fiber is a cellulose polymer just like other natural fibers such as cotton and ramie. The structure of flax is crystalline, which make it stronger but it easily gets wrinkles. Flax fibers are very popular in linen knitted and woven clothing, flax fibers are used for home textile accessories like tablecloth, bed linen and curtains [26]. In [45], flax fiber was compared with conventional glass fiber. It was reported that the reason which makes flax fiber more appealing than glass fiber is that it is cheaper than glass fiber, less toxic and has a high strength to weight ratio [45]. Flax fiber has various advantages: it is biodegradable, it has less carbon footprint than other natural fibers, it requires less water and pesticides for cultivation, it has excellent tensile strength, and good U.V protection [46]. This fiber has some limitations for application in composites. Flax fiber degrades above $200^{\circ} \mathrm{C}$ and due to moisture retention it cannot be used in external applications. Just like other fibers, flax has variations in properties and irregular shape [47].

\section{G. Kenaf}

Kenaf fiber belongs to genus Hibiscus cannabinus, $\mathrm{K}$ Family Malvaceae, there are over 300 species related to kenaf fiber. Kenaf due to its environment-friendly properties is preferred in composite products [12]. Kenaf plant can grow in a wide range of climatic conditions and it is one of the fastest growing plants. Kenaf has appealing characteristics like lowdensity, it is non-abrasive during processing and has high specific mechanical properties. The plant absorbs nitrogen and phosphorus from the soil and $\mathrm{CO}_{2}$ at a high rate [48]. Kenaf is a well-known cellulosic fiber having ecological and economic advantages [7]. Kenaf fiber is traditionally used in ropes, canvas, and stacking, and nowadays is being used in composites in automobiles, aeronautics etc. [49].

TABLE IV. WORLD PRODUCTION OF NATURAL FIBERS, PRODUCING COUNTRIES, AND APPLICATIONS IN PROTECTIVE TEXTILES AND OTHER COMPOSITES

\begin{tabular}{|c|c|c|c|c|}
\hline Name & $\begin{array}{l}\text { World production } \\
\text { rate (000) }\end{array}$ & Country of origin & Application & Reference \\
\hline Abaca & (1) & $\begin{array}{l}\text { Native to Philippines and } \\
\text { tropical countries }\end{array}$ & $\begin{array}{c}\text { Automobile, and airplane, geo-textiles, bank notes, security paper, and } \\
\text { tea bags }\end{array}$ & {$[12,27]$} \\
\hline Bamboo & 30000 & $\begin{array}{l}\text { China, Japan, and other Asian } \\
\text { countries }\end{array}$ & $\begin{array}{l}\text { Construction industry. Cut resistance gloves, sun protection clothing, } \\
\text { anti-bacterial clothing }\end{array}$ & {$[12,34-36]$} \\
\hline Coir & 100 & Sri Lanka & $\begin{array}{c}\text { Used in bulletproof vests, building boards, roofing sheets, insulation } \\
\text { boards, building panels, coir fiber reinforced composites, cement } \\
\text { boards, geo-textiles. }\end{array}$ & {$[29-33]$} \\
\hline Flax & 830 & $\begin{array}{l}\text { Russia Poland, France, Belgium, } \\
\text { and the Czech Republic }\end{array}$ & $\begin{array}{l}\text { Fire protection, medical textiles as surgical thread, clothing, insulation, } \\
\text { filtration, light aviation use. }\end{array}$ & {$[12,45,47]$} \\
\hline Hemp & 214 & $\begin{array}{c}\text { Poland, Romania, Russia, } \\
\text { Slovenia, Spain and Switzerland }\end{array}$ & $\begin{array}{l}\text { Military uniforms, special uniforms requiring antibacterial properties, } \\
\text { insulations, waterproofing, windproof, sunscreen, anti-infrared flame } \\
\text { resistance. }\end{array}$ & {$[44,50]$} \\
\hline Jute & 2300 & Bangladesh, India and China & Plywood, medium density fiberboards, panel and plush doors. & {$[12,39-42]$} \\
\hline Kenaf & 970 & China and India & Composites, automobiles, paper industry, and fiber boards. & {$[12,49]$} \\
\hline Ramie & 100 & China & $\begin{array}{l}\text { Bulletproof vests, industrial sewing threads, packaging material, } \\
\text { fishing nets, filter cloths, and home furnishing cloths. }\end{array}$ & {$[12,26,43-44]$} \\
\hline
\end{tabular}

\section{FUTURE CHALLENGES}

Limited research is conducted in the field of hybridization of conventional (plastic-based fiber) and natural fiber. Ecofriendly, low weight, low-cost PC can be developed through hybridization of conventional fibers like Kevlar, Dynema, Spectra and natural fibers like jute, ramie, sisal, coir and bamboo with the selection of suitable design and the appropriate ratio of fiber mix. Abaca fiber due to its high mechanical strength properties is a potential candidate to use in protective clothing (research is required). Bamboo fiber, due to its inherent antimicrobial and antifungal properties, could be hybridized with Nomex fiber and other conventional fibers for application in firefighter suits and medical textiles as a biological protective application. For the improvement of properties like moisture barrier, antifungal and antibacterial abilities, more research is required in this field. Ramie and coir are the strongest natural fibers and can be utilized in protective clothing. Limited research has been made to utilize ramie fiber in bulletproof panels. More research is required for the utilization of ramie fiber in other applications of protective clothing like hand gloves, sleeves etc.

\section{CONCLUSION}

Natural fiber-based composite protective clothing and other composites have developed significantly due to their environmental, economic, technological and legal benefits. These natural fiber based composites are finding applications in various fields including protective clothing. Review and examination of various studies highlighted the importance of environmental issues which occur due to plastic pollution, which can overcome by reducing the plastic based conventional fibers with natural fiber composites. A very limited research has been carried out in this area, however, during the past decade, various researchers focused on the development of eco-friendly materials for different applications including protective clothing.

\section{REFERENCES}

[1] D. C. Wilson, L. Rodic, P. Modak, R. Soos, A. Carpintero, C. Velis, M. Iyer, O. Simonett, Global Waste Management Outlook, 2018

[2] R. Geyer, J. R. Jambeck, K. L. Law, "Production, use, and the fate of all plastic ever made", Science Advances, Vol. 3, No. 17, ArticleID e1700782, 2017

[3] V. Merino, D. Ayer, C. LeChevet, R. Larrivee, M. Ergastolo, L. Robledo, Plastic Pollution Primer and Action Toolkit, Earth Day Network, 2018 
[4] L. Mohammad, M. N. M. Ansari, G. Pua, M. Jawaid, M. S. Islam, “A Review of Natural Fiber Reinforced Polymer Composite and Its Applications", International Journal of Polymer Science, Vol. 2015, Article ID 243947, 2015

[5] R. Shishoo, "Recent developments in materials for use in protective clothing“, International Journal of Clothing Science and Technology, Vol. 14, No. 3-4, pp. 201-215, 2002

[6] J. W. S. Hearle, "Fiber and fabrics for protective textiles", in: Textiles for Protection, Woodhead Publishing \& Textile Institute, 2005

[7] T. Nishino, K. Hirao, M. Kotera, K. Nakamae, H. Inagaki, "Kenaf reinforced biodegradable composite", Composites Science and Technology, Vol. 63, No. 9, pp. 1281-1286, 2003

[8] Z. Salman, "Negative Impacts of Incineration-Based Waste-to-Energy Technology", available at: http://www.alternative-energynews.info/negative-impacts-waste-to-energy, 2018

[9] A. K. Lau, W. W. Cheuk, K. V. Lo, "Degradation of greenhouse twines derived from natural Fibres and biodegradable polymer during composting", Journal of Environmental Management, Vol. 90, No. 1, pp. $668-671,2008$

[10] A. Sivan, "New perspectives in plastic biodegradation", Current Opinion in Biotechnology, Vol. 22, No. 3, pp. 422-426, 2011

[11] M. Shimao, "Biodegradation of Plastics", Current Opinion in Biotechnology, Vol. 12, No. 3, pp. 242-247, 2001

[12] O. Faruk, A. K. Beldzki, H. P. Fink, M. Sain, "Bio-composites reinforced with natural Fibres: 2000-2010", Progress in Polymer Science, Vol. 37, pp. 1552-1596, 2012

[13] National Research Council, Division on Engineering and Physical Sciences, National Materials Advisory Board, Committee on HighPerformance Structural Fibers for Advanced Polymer Matrix Composites, High-Performance Structural Fibres for Advanced Polymer Matrix Composites, National Academies Press, 2005

[14] T. Jackson Singh, S. Samanta, "Characterization of Kevlar Fiber and its composites: A Review", 4th International Conference on Materials Processing and Characterization, Materials Today Proceedings, Vol .2 No. 4-5, pp. 1381-1387, 2015

[15] http://www.technologystudent.com/joints/kevlar2.html

[16] http://www.dupont.pk/products-and-services/fabrics-fibersnonwovens/fibers/brands/kevlar.html

[17] P. N. B. Reis, J. A. M. Ferreira, J. D. M. Coata, M. J. Santos, "Fatigue Performance of Kevlar/Epoxy Composites with Filled Matrix by Cork Powder", Fibres and Polymers, Vol. 13, No. 10, pp. 1292-1299, 2012

[18] T. Matsuo, "Fiber Materials for advance technical textile", Textile Progress, Vol. 40, No. 2, pp. 87-121, 2008

[19] M. Kurtz, UHMWPE Biomaterial Handbook, Elsevier, 2015

[20] B. Gua, L. J. Wang, P. Yin, B. G. Li, P. X. Li, "Ultra-high molecular weight polyethylene fiber-reinforced thermoplastic corn starch composite", Journal of Thermoplastic Composite Materials, Vol. 30, No. 4, pp. 564-577, 2017

[21] S. Cao, H. Liu, S. Ge, G. Wu, "Mechanical and tribological Behaviours of UHMWPE composites filled with basalt Fibres", Journal of Reinforced Plastics \& Composites, Vol. 30, No. 4, pp. 347-355, 2011

[22] D. Das, A. K. Pradhan, R. Chattopadhyay, S. N. Singh, "Composite Nonwovens", Textile Progress, Vol. 44, No. 1, pp. 1-84, 2012

[23] S. Adanur, Handbook of Industrial Textiles, Wellington Sears, 1995

[24] T. Windhorst, G. Blount, "Carbon-Carbon Composites; A summary of recent developments and applications", Material \& Design, Vol. 18, No. 1, pp. 11-15, 1997

[25] C. Scarponi, "Carbon -Carbon composite in aerospace engineering", in: Advance Composite Material for Aerospace. Engineering, Processing, Properties and Applications, pp. 385-412, Elsevier, 2016

[26] R. S. Blackburn, Biodegradable and Sustainable Fibres, The Textile Institute \& Woodhead Publishing, 2005

[27] R. B. Armecin, F. G. Sinon, L. O. Moreno, “Abaca Fiber: A Renewable Bio-resource for Industrial Uses and Other Applications", in: Biomass and Bioenergy-Applications, Springer, pp. 108-116, 2014
[28] M. Zimniewska, A Kicinska-Jakubowska, "Vegetable fibres sheet", available at: http://dnfi.org/wp-content/uploads/2012/01/fact-sheet-plantfibers.pdf, 2018

[29] A. Rajan, T. E. Abraham, "Coir Fiber-process and Opportunities”, Journal of Natural Fibres, Vol. 3, No. 4, pp. 29-41, 2008

[30] C. R. Rajeesh, K. K Saju, "Methods and materials for reducing flammability behavior of coir fiber based Composite Boards: A Review", Materials Today: Proceedings, Vol. 4, No. 9, pp. 9399-9407, 2017

[31] F. S. da Luz, S. N. Monteiro, E. S. Lima, E. Pereira Lima Jr, "Ballistic Application of Coir Fiber Reinforced Epoxy Composite in Multi-layered Armour", Material Research, Vol. 20, No. 2, pp. 23-28, 2017

[32] P. Darsana, R. Abraham, A. Joseph, A. Jasheela, P. R. Binuraj, J. Sarma, "Development of Coir Fiber Cement Composite roofing tiles", Procedia Technology, Vol. 24, pp. 169-178, 2016

[33] B. Lipp-Symonowicz, S. Sztajnowski, D. Wojciechowska, "New Commercial Fibres Called 'Bamboo Fibres'-Their Structure and properties", Fiber \& Textiles in Eastern Europe, Vol. 19, No. 1, pp. 1823, 2011

[34] N. Erdumlu, B. Ozipek, "Investigation of Regenerated Bamboo Fibre and Yarn Characteristics", Fibres \& Textiles in Eastern Europe, Vol. 16, No. 4, pp. 43-47, 2008

[35] T. Shito, K. Okubo, T. Fujii, "Development of eco-composites using natural bamboo Fibres and their mechanical properties", in: WIT Transactions on The Built Environment, Vol. 59, 2002

[36] M. Waite, "Sustainable Textiles: The Role of Bamboo and a Comparison of Bamboo Textile properties (Part II)", Journal of Textile and Apparel Technology and Management, Vol. 6 No. 3, pp. 1-21, 2010

[37] J. K. Huang, W. B. Young, "The mechanical, hygral, and interfacial strength of continuous bamboo fiber reinforced epoxy composites", Composites Part B: Engineering, Vol. 166, pp. 272-283, 2018

[38] http://naturalfibres2009.org/en/fibres/jute.html

[39] R. Bhanupratap, H. C. Chittappa, "Study of Tensile Behaviour by variation of Kevlar to Jute Fiber epoxy Hybrid Composite", International Journal of Engineering Research \& Technology, Vol. 6, No. 6, pp. 10391043, 2017

[40] S. Maity, K. Singha, D. Prasad Gon, P. Paul, M. Singha, "A Review on Jute Nonwovens: Manufacturing, Properties, and Applications", International Journal of Textile Science, Vol. 1, No. 5, pp. 36-43, 2012

[41] P. Ray, M. Datta, "Jute in Technical Textile", $1^{\text {st }}$ China International Bast Fibrous Plants and Textile Conference (China), 2004

[42] E. Marsyahyo, Jamsari, H. S. B. Rochardjo, Soekrisno, "Preliminary Investigation on Bulletproof Panels Made from Ramie Fiber Reinforced Composites for NIJ Level II, IIA, and IV", Journal of Industrial Textiles, Vol. 16, pp. 474-47, 2009

[43] T. Sen, H.N. Jagannatha Reddy, "Various Industrial Applications of Hemp, Kenaf, Flax and Ramie Natural Fibres", International Journal of Innovations, Management, and Technology, Vol. 2, No. 3, pp. 192-198, 2011

[44] J. Zhu, H. Zhu, J. Njuguna, H. Abhyyankar, "Recent Development of Flax Fibres and Their Reinforced Composites Based on Different Polymeric Matrices", Materials (Basel), Vol. 6, No. 11, pp. 5171-5198, 2013

[45] NORAFIN, The Advantages of Flax Fibres in Composites, 2009

[46] S. M. Kurtz, "UHWMPE in Total Joint Replacement and Medical Devices", in: UHWMPE Bio Material Handbook, Elsevier, 2004

[47] K. Abe, Y. Ozaki, "Comparison of useful terrestrial and aquatic plant species for removal of nitrogen and phosphorus from domestic water", Soil Science and Plant Nutrition, Vol. 44, No. 4, pp. 599-607, 1998

[48] S. Sreenivasan, S. Sulaiman, B. T. H. T. Baharudin, M. K. A. Ariffin, K. Abdan, "Recent Developments of Kenaf Fiber Reinforced Thermoset Composites: A Review", Material Research Innovations, Vol. 17, No. 2, pp. s2-s11, 2013

[49] H. Zhang, Z. Zhong, L. Feng, "Advances in the Performance and Application of Hemp Fiber", International Journal of Simulation Systems, Science \& Technology, Vol. 17, No. 9, Paper 18, 2018 